\title{
Short-term Controlled Atmosphere Storage Improved Quality of Several Apple Cultivars
}

\author{
S.R. Drake ${ }^{1}$ \\ US. Department of Agriculture, Agricultural Research Service, Tree Fruit Research Laboratory, I104 \\ North Western Avenue, Wenatchee, WA 98801 \\ Additional index words. firmness, acidity, color

\begin{abstract}
Controlled atmosphere (CA) storage for 30 or 60 days reduced quality losses for 'Jonagold', 'Golden Delicious', 'Delicious', 'Granny Smith', and 'Fuji' apples ( Malus domestica Borkh.). After 30 days 'Jonagold' and 'Golden Delicious' from CA were firmer, had higher acidity, and were less yellow (more green) than apples from regular atmosphere (RA) storage. 'Delicious' and 'Granny Smith' were firmer after 60 days of CA storage than fruit from RA. In addition, 'Granny Smith' from CA had more acid and were greener than apples from RA. After 8 days of ambient storage, little loss in firmness and no loss in acid content occurred with 'Jonagold' or 'Golden Delicious' from CA compared to the significant loss in firmness and acid when stored in RA. After ambient storage for 8 days, 'Jonagold', 'Golden Delicious', and 'Granny Smith' retained a freshly harvested apple color with more green and less yellow development when stored in CA rather than RA. In 'Fuji', the treatments had no effect except for improved acid retention if stored in CA. A combination of 30 days CA followed by 30 days RA produced 'Jonagold', 'Golden Delicious', and 'Delicious' that were superior in quality to apples from 60 days RA.
\end{abstract}

Present controlled atmosphere (CA) storage in Washington State (WAC, 1989), established in 1964, requires that before fruit can be certified as CA, apples must be stored for 90 days at $5 \% \mathrm{O}_{2}$ or less, and the $\mathrm{O}_{2}$, requirement must be met within 20 days after the room is sealed. Since these requirements were established, technology has advanced and CA conditions can be at $1 \% \mathrm{O}_{2}$ in a matter of hours. There is no doubt that long-term storage in CA has enhanced the dessert quality of apples (Lidster et al., 1980; Mattheis and Olsen, 1989; Meheriuk, 1991; Meheriuk and Pruitt, 1973; Meheriuk, et al., 1984; Patterson and Nichols, 1988; Patterson and Workman, 1962; Olsen, 1969; Olsen and Schemer, 1964). If new technology of establishing very low $\mathrm{O}_{2}$ levels quickly is taken into consideration, there is good reason to believe that early storage quality advantages would be present. Some research (Couey and Olsen, 1975; Lau and Looney, 1978; Olsen and Barnum, 1978; Wang and Mellenthin, 1975) has been concerned with short-term changes in CA atmospheres, but after this short period of time, normal CA patterns were established for long-term storage. No research has been conducted on apple response to short-term (60 days or less) CA storage.

\section{Materials and Methods}

Apples from three trees each of 'Delicious', 'Golden Delicious', 'Granny Smith', and 'Fuji' were harvested at commercial maturity (WAMP, 1986) and 7 to 10 days later, for two harvest seasons 1990-91. 'Jonagold' was harvested at commercial maturity for only two seasons. Immediately after harvest, the fruit was graded and sorted for uniform size. Acceptable fruit (360 per harvest or 120 per tree) for each crop season and cultivar were divided into two groups and stored at $1 \mathrm{C}$ in either RA or CA storage. CA conditions for 'Delicious', 'Granny Smith', and 'Fuji' were $1 \% \quad \mathrm{O}_{2}$ and $1 \% \quad \mathrm{CO}_{2}$; 'Golden Delicious' and 'Jonagold' were $1 \% \mathrm{O}_{2}$, and $3 \% \mathrm{CO}_{2}$. Atmospheres were established and maintained

Received for publication 22 June 1992. Accepted for publication 14 Nov. 1992. I wish to express appreciation to the Washington State Tree Fruit Research Commission for grant funds partially supporting the study. The cost of publishing this paper was defrayed in part by the payment of page charges. Under postal regulations, this paper therefore must be hereby marked advertisement solely to indicate this fact. Research Horticulturist. with a computer-controlled system (Technical Consulting Services, Chelan, Wash.). Nitrogen was supplied by a Generon Membrane Separation System (Generon, Houston). After 30 and 60 days of storage, apples were removed and quality comparisons made between RA and CA storage. A portion of the fruit was removed after 30 days from $\mathrm{CA}$ and stored an additional 30 days under RA. Fruit that had received a combination of CA and RA (30/ 30) storage were compared with fruit from 60 days of RA or CA storage alone. Analysis of 'Jonagold', 'Golden Delicious', 'Delicious', and 'Fuji' was determined immediately after removal from storage and after 8 days ambient temperature $(\approx 21 \mathrm{C})$ storage and after 10 days ambient storage for 'Granny Smith'. Twenty fruit (storage type/storage time/rep) were used for quality analysis.

External and internal color was determined with The Color Machine (Pacific Scientific, Silver Springs, Md.) using the Hunter L,a,b system and calculated hue values (Hunter and Harold, 1987). Three evaluations for each fruit were used for external color, and one evaluation was used for internal color determination. Firmness was determined using a Lake City Pressure Tester model EPI (Kelowna, B.C.) equipped with a $1.1-\mathrm{cm}$ probe. Titratable acidity was determined with a Radiometer titrator, Model TTT85 (Radiometer. Copenhagen, Denmark). Acids were titrated to $\mathrm{pH} 8.2$ with $0.1 \mathrm{~N} \mathrm{NaOH}$ and expressed as percent malic acid. A factorial design with storage type, storage time, ambient storage, and replication was used for data analysis. No difference in storage response was noted between harvest dates; therefore, harvest dates were combined for data analysis. Analysis of variance was by MSTAT (1989). Based on significant F tests, means were separated by Tukey's honestly significant difference test (HSDT).

\section{Results}

Firmness values for 'Jonagold' and 'Golden Delicious' apples were strongly influenced by storage atmosphere at 30 days after harvest (Table 1). A firmness loss of $15.2 \%$ and $9.3 \%$ was determined for 'Jonagold' and 'Golden Delicious', respectively, for those apples stored 30 days in RA compared with identical apples

Abbreviations: CA, controlled atmosphere; RA, regular atmosphere: TA, acid concentration. 
Table 1. Firmness (newtons) of 'Jonagold', 'Goldes Delicious', 'Gramny Sinith', and 'Fuji' apples as influenced by storage atmosphere and time and storage atmosphere and ripening.

\begin{tabular}{|c|c|c|c|c|c|c|c|}
\hline \multicolumn{2}{|c|}{ Storage } & \multirow{3}{*}{-} & \multirow[b]{2}{*}{ 'Jonagold' } & \multirow[b]{2}{*}{ 'Golden Delicious' } & \multirow[b]{2}{*}{ 'Delicious' } & \multirow[b]{2}{*}{ 'Granny Smith' } & \multirow[b]{2}{*}{ 'Fuji' } \\
\hline Type & Time (days) & & & & & & \\
\hline \multirow[t]{2}{*}{$\overline{\mathrm{RA}}$} & 30 & & $\overline{59.6 b^{2}}$ & $61.8 \mathrm{~b}$ & $70.7 \mathrm{a}$ & $79.2 \mathrm{ab}$ & $82.8^{\mathrm{Ns}}$ \\
\hline & 60 & & $51.2 \mathrm{c}$ & $55.1 \mathrm{c}$ & $65.4 \mathrm{~b}$ & $77.8 \mathrm{~b}$ & 81.4 \\
\hline \multirow[t]{3}{*}{$\mathrm{CA}$} & 30 & & $70.3 a$ & $68.1 \mathrm{a}$ & $71.6 \mathrm{a}$ & $81.4 \mathrm{a}$ & 83.8 \\
\hline & 60 & & $68.5 \mathrm{a}$ & $66.7 \mathrm{a}$ & $70.7 a$ & $81.0 \mathrm{a}$ & 79.2 \\
\hline & $\begin{array}{c}\text { Ripening } \\
\text { time (days) }\end{array}$ & & & & & & \\
\hline \multirow[t]{2}{*}{ RA } & 0 & & $63.2 \mathrm{c}$ & $63.6 \mathrm{c}$ & $73.4 \mathrm{a}$ & $80.1 \mathrm{a}$ & $81.4^{\mathrm{ss}}$ \\
\hline & 8 & & $46.6 \mathrm{~d}$ & $60.5 \mathrm{~d}$ & $62.7 \mathrm{c}$ & $76.5 \mathrm{~b}$ & 82.9 \\
\hline \multirow[t]{2}{*}{$\mathrm{CA}$} & 0 & & $72.9 \mathrm{a}$ & $68.9 \mathrm{a}$ & $74.7 \mathrm{a}$ & $81.4 \mathrm{a}$ & 80.2 \\
\hline & 8 & & $65.8 \mathrm{~b}$ & $65.8 \mathrm{~b}$ & $67.6 \mathrm{~b}$ & $81.0 \mathrm{a}$ & 80.8 \\
\hline
\end{tabular}

${ }^{7}$ Mean separation within groups by Tukey's $\overline{\mathrm{HSDT}}(P \geq 0.05)$.

y Ten days of ripening for 'Granny Smith' apples.

Table 2. Titratable acid content (\%) of 'Jonagold', 'Golden Delicious', 'Granny Smith', and 'Fuji' apples as influenced by storage type and time.

\begin{tabular}{|c|c|c|c|c|c|c|}
\hline \multicolumn{2}{|c|}{ Storage } & \multirow[b]{2}{*}{ 'Jonagold' } & \multirow[b]{2}{*}{ 'Golden Delicious' } & \multirow[b]{2}{*}{ 'Delicious' } & \multirow[b]{2}{*}{ 'Granny Smith' } & \multirow[b]{2}{*}{ 'Fuji' } \\
\hline Type & Time (days) & & & & & \\
\hline \multirow[t]{2}{*}{$\overline{\mathrm{RA}}$} & 30 & $0.43 b^{7}$ & $0.32 \mathrm{~b}$ & $0.21^{\mathrm{ss}}$ & $0.76 \mathrm{~b}$ & $0.29 \mathrm{~b}$ \\
\hline & 60 & $0.40 \mathrm{c}$ & $0.30 \mathrm{~b}$ & 0.20 & $0.76 \mathrm{~b}$ & $0.29 \mathrm{~b}$ \\
\hline \multirow[t]{2}{*}{$\mathrm{CA}$} & 30 & $0.45 \mathrm{a}$ & $0.37 \mathrm{a}$ & 0.21 & $0.80 \mathrm{a}$ & $0.31 \mathrm{a}$ \\
\hline & 60 & $0.45 \mathrm{a}$ & $0.35 a$ & 0.21 & $0.78 \mathrm{a}$ & $0.32 \mathrm{a}$ \\
\hline
\end{tabular}

¿Mean separation by Tukey's HSDT $(P \geq 0.05)$.

Table 3. Hunter color values for 'Jonagold', 'Golden Delicious', and 'Granny Smith' apples as influenced by storage type, time, and ripening period.

\begin{tabular}{|c|c|c|c|c|c|c|c|c|c|}
\hline \multirow[b]{2}{*}{ Storage type } & \multicolumn{3}{|c|}{ 'Jonagold' } & \multicolumn{3}{|c|}{ 'Golden Delicious' } & \multicolumn{3}{|c|}{ 'Granny Smith' } \\
\hline & L & $\mathrm{b}$ & Hue & $\mathrm{L}$ & $\mathrm{b}$ & Hue & $\mathbf{L}$ & a & Hue \\
\hline$\overline{\mathrm{RA}}$ & $69.3 \mathrm{a}^{2}$ & $32.6 \mathrm{a}$ & $99.2 \mathrm{~b}$ & $75.4 \mathrm{a}$ & $35.8 \mathrm{a}$ & $118.0 \mathrm{~b}$ & $63.9 \mathrm{a}$ & $27.7 \mathrm{a}$ & $108.5 b$ \\
\hline $\mathrm{CA}$ & $68.1 \mathrm{~b}$ & $31.1 \mathrm{~b}$ & $103.3 \mathrm{a}$ & $74.0 \mathrm{~b}$ & $34.1 \mathrm{~b}$ & $124.5 \mathrm{a}$ & $63.1 \mathrm{~b}$ & $26.9 \mathrm{~b}$ & $109.9 \mathrm{a}$ \\
\hline \multicolumn{10}{|l|}{ Storage time } \\
\hline 30 days & $68.1 \mathrm{~b}$ & $32.2 \mathrm{a}$ & $101.8^{\mathrm{ss}}$ & $74.7^{\mathrm{Ns}}$ & $34.7 \mathrm{~b}$ & $122.5 \mathrm{a}$ & $63.7^{\mathrm{vs}}$ & $27.0 \mathrm{~b}$ & $109.6 \mathrm{a}$ \\
\hline 60 days & $69.3 \mathrm{a}$ & $31.5 \mathrm{~b}$ & 100.8 & 74.6 & $35.2 \mathrm{a}$ & $120.0 \mathrm{~b}$ & 63.4 & $27.6 \mathrm{a}$ & $108.9 \mathrm{~b}$ \\
\hline \multicolumn{10}{|c|}{ Ripening time ${ }^{y}$} \\
\hline 0 days & $67.2 \mathrm{~b}$ & $30.9 \mathrm{~b}$ & $101.6^{\mathrm{NS}}$ & $73.1 \mathrm{~b}$ & $33.3 \mathrm{~b}$ & $127.2 \mathrm{a}$ & $63.1 \mathrm{~b}$ & $26.7 \mathrm{~b}$ & $109.5 \mathrm{a}$ \\
\hline 8 days & $70.3 \mathrm{a}$ & $32.7 \mathrm{a}$ & 101.0 & $76.3 a$ & $36.6 \mathrm{a}$ & $115.3 \mathrm{~b}$ & $64.0 \mathrm{a}$ & $27.9 \mathrm{a}$ & $108.9 \mathrm{~b}$ \\
\hline
\end{tabular}

${ }^{2}$ Mean separation within groups by analysis of variance $(P \geq 0.05)$.

y'Ten days ripening for 'Granny Smith' apples.

from 30 days in CA. By the end of 60 days of storage, firmness in apples from RA compared to CA storage had decreased by $25.3 \%$ and $17.4 \%$ for 'Jonagold' and 'Golden Delicious', respectively. Firmness values for 'Delicious' were not different after 30 days RA and CA storage, but after 60 days of storage, 'Delicious' from CA were $7.5 \%$ firmer than those from RA.

'Granny Smith' from CA storage consistently averaged $3.5 \%$ or $2.7 \mathrm{~N}$ higher than 'Granny Smith' apples from RA storage. Firmness values of 'Fuji' apples were similar regardless of storage or duration.

Firmness values of 'Jonagold', 'Golden Delicious', 'Delicious', and 'Granny Smith' from RA storage declined more rapidly during the ambient storage period than similar apples from CA storage (Table 1). Firmness of 'Jonagold' from RA storage declined $24.7 \%$ during 8 days at ambient temperature; however, over the same period, the decline in firmness values for apples from CA storage was only $9.7 \%$. This more rapid decline in firmness of apples from RA storage during ambient temperature storage was also evident for 'Delicious' but not to the same extent. 'Delicious' from RA storage lost $14.6 \%$ of their firmness during ambient temperature storage compared to $9.5 \%$ for 'Delicious' from CA storage.

The decline in firmness during ambient temperature storage of 'Granny Smith' was only apparent when the apples were from RA storage. 'Granny Smith' from CA did not decline in firmness after 8 days at ambient temperature. Except for 'Fuji', CA apples were firmer than RA apples after 8 days at ambient temperature. For 'Jonagold' and 'Golden Delicious', this difference in firmness was evident before the initiation of ambient temperature storage.

Acid content (TA) of 'Jonagold', 'Golden Delicious', 'Granny 
Smith', and 'Fuji' was superior in CA apples regardless of storage time (30 or 60 days) when compared to identical RA apples (Table 2). Differences in acid content between RA and CA storage types was particularly large for 'Jonagold' and 'Golden Delicious' and moderate for 'Granny Smith' and 'Fuji'. Acid content of 'Delicious' from RA or CA was similar regardless of storage or time.

Time in storage had a distinct influence on the acid values of 'Jonagold'. As storage time progressed from 30 to 60 days, acid decreased for 'Jonagold' from RA, but not for those from CA storage. After 60 days of CA storage, only 'Delicious' had acid concentrations equal to apples from RA storage. In all other instances, acid concentration was highest in CA apples regardless of storage time.

Both storage conditions visibly affected 'Jonagold', 'Golden Delicious', and 'Granny Smith' color (Table 3). In these three cultivars, CA stored apples were darker (lower Hunter ' $L$ ' values) and were less yellow (lower Hunter 'b' value), i.e, greener (higher 'hue' value), than similar apples from RA storage. This color difference between RA and CA storage was visually apparent. As storage time progressed from 30 to 60 days. color changed in all three cultivars ('Jonagold', 'Golden Delicious', and 'Granny Smith'). Apples from 60 days' storage, particularly 'Golden Delicious' and 'Granny Smith', were lighter in color with a distinct change in Hunter ' $b$ ' and hue values (yellower, less green appearance). 'Jonagold' apples became lighter in color as storage time progressed, i.e., more yellow (Hunter 'b'). Apple color became lighter (higher Hunter ' $L$ ' values) in all three cultivars during 8 days of ripening. No change in hue values was evident for 'Jonagold' after 8 days of ambient-temperature storage, but 'Golden Delicious' and 'Granny Smith' lost green pigmentation and became a more pronounced yellow during ambient temperature storage.

Time in storage resulted in a color change for 'Delicious' apples (Table 4) but not for 'Fuji' (ranges: L, 60.7-60.9; b, 4.5-5.7; hue, 75.3-77.3). 'Delicious' apples from CA storage were lighter in color with less red development coupled with a higher hue value (more yellow). Ripening time had no influence on color for 'Fuji' and only a slight influence on 'Delicious'. In 'Delicious', as ripening time progressed, there was an increase in hue values toward a yellower color.

'Jonagold', 'Golden Delicious', and 'Delicious' apples from CA were firmer than apples from RA storage. 'Jonagold', 'Golden Delicious', and 'Delicious' subjected to a combination storage of 30 days of CA followed by 30 days of RA (CA/RA) were firmer than apples from RA only (Table 5). In the case of 'Delicious', firmness was nearly identical for CA and CA/RA storage. 'Jonagold'

Table 4. Hunter color values for 'Delicious' apples as influenced by storage type, time, and ripening period.

\begin{tabular}{|c|c|c|c|}
\hline \multirow[b]{2}{*}{ Storage type } & \multicolumn{3}{|c|}{ 'Delicious" } \\
\hline & $\mathrm{L}$ & $\mathrm{b}$ & Hue \\
\hline$\overline{\mathrm{RA}}$ & $41.4^{\mathrm{NS}^{7}}$ & $22.3 \mathrm{a}^{2}$ & $26.6^{\sqrt{5}}$ \\
\hline $\mathrm{CA}$ & 41.1 & $20.7 \mathrm{~b}$ & 27.8 \\
\hline \multicolumn{4}{|l|}{ Storage time } \\
\hline 30 days & 40.5 & $21.9 \mathrm{a}$ & 25.8 \\
\hline 60) days & 42.0 & $21.1 \mathrm{~b}$ & 28.5 \\
\hline \multicolumn{4}{|c|}{ Ripening time } \\
\hline 0 days & 41.6 & $21.4^{\mathrm{vs}}$ & 26.1 \\
\hline 8 days & 41.0 & 21.6 & 28.3 \\
\hline
\end{tabular}

${ }^{2}$ Mean separation within groups by analysis of variance $(P \geq 0.05)$. and 'Golden Delicious' from CA/RA storage were softer than those for apples from CA storage but firmer than those for apples from RA storage. No firmness differences were present for 'Granny Smith' or 'Fuji' when apples from CA/RA storage were compared with CA or RA storage alone (data not shown).

Acid's for 'Jonagold' and 'Golden Delicious' after 60 days of CA/RA storage were intermediate between those determined for apples from CA (highest) and RA (lowest) alone. Acid's for 'Delicious', 'Granny Smith'. and 'Fuji' were similar in all three storage types (data not shown).

\section{Discussion}

Not only consumers but state and federal inspectors use apple texture or firmness as an indicator of quality. Other attributes used to judge fruit quality can include flavor and color. Almost immediately after an apple is harvested quality starts to decline. This decline can be slowed by low temperature (RA) and slowed even more by manipulation of the atmosphere (CA). How rapidly quality declines during either RA or CA storage depends on the cultivar. Historically, CA storage has been used to increase market availability of apples over a 12-month season. However, there are quality advantages for apples after only a short storage time in CA. In this study, response time to CA was cultivar dependent. CA storage of only 30 days after harvest resulted in a significant reduction in quality losses of 'Jonagold' and "Golden Delicious' apples, the two softer cultivars. CA storage of 60 days resulted in a reduction of quality losses for 'Delicious' and 'Granny Smith' apples.

Differences in firmness values for apples stored under shortterm CA could be the determining factor in fruit meeting market requirements, particularly in the case of soft cultivars such as 'Jonagold' or 'Golden Delicious'. where firmness values were significantly (6 to $10 \mathrm{~N}$ ) different between CA and RA storage in a short term (30 days). A high acid content produces an apple with more flavor. Higher acid content was present in apples from shortterm CA for all apple cultivars used in this study, except 'Delicious'. 'Granny Smith' apples in RA and CA storage contained sufficient acid for good flavor. Acid content of 'Jonagold', 'Golden Delicious', and 'Fuji' was enhanced with the use of CA storage. Lack of color change for 'Jonagold', 'Golden Delicious', and 'Granny Smith' from CA storage could be used for market advantage. Many markets preferrelatively green 'Jonagold' and 'Golden Delicious'. In the case of 'Granny Smith', the amount of green pigmentation present reflects directly on the fruit grade.

A combination (CA/RA) of the two storage types could improve the quality of apples in the market. The ideal conditions for

Table 5. Firmness $(\mathrm{N})$ and acid content $(\%)$ after 60 days of storage for 'Jonagold', 'Golden Delicious', and 'Delicious' apples.

\begin{tabular}{lccc}
\hline \hline Firmness & 'Jonagold & 'Golden Delicious' & 'Delicious' \\
\hline RA & $52.1 \mathrm{c}^{\prime}$ & $54.4 \mathrm{c}$ & $65.3 \mathrm{~b}$ \\
$\mathrm{CA}$ & $65.6 \mathrm{a}$ & $66.9 \mathrm{a}$ & $70.6 \mathrm{a}$ \\
$\mathrm{CA} / \mathrm{RA}^{\mathrm{y}}$ & $58.9 \mathrm{~b}$ & $64.6 \mathrm{~b}$ & $70.4 \mathrm{a}$ \\
& & & \\
Acids & & & $0.21^{\mathrm{Ns}}$ \\
RA & $0.40 \mathrm{~b}$ & $0.34 \mathrm{c}$ & 0.20 \\
CA & $0.45 \mathrm{a}$ & $0.40 \mathrm{a}$ & 0.20 \\
CA/RA & $0.42 \mathrm{ab}$ & $0.38 \mathrm{~b}$ & \\
\hline
\end{tabular}

${ }^{\overline{2}}$ Mean separation by Tukey's HSDT $(P \geq \overline{0.05)}$.

yThirty days of CA storage followed by 30 days of RA storage. 
good quality apples would be to use CA in both storage and during transit of 60 or more days. Presently, most apples for early shipment are stored and shipped in RA only. Apples that receive 30 days of CA before transit (RA) should arrive in better condition than apples stored in RA only through the storage and transit period.

Good quality fruit is in demand for export and some of the largest demand for U.S. grown apples is from November through January, which is at or near the end of the quality life of RA-stored fruit. Apples stored under a short-term CA environment (60 days or less) would be in better condition than apples from RA and, subsequently, would be of higher quality on the early export market.

\section{Literature Cited}

Couey, H.M. and K.L. Olsen. 1975. Storage response of 'Golden Delicious' apples after high carbon dioxide treatment. J. Amer. Soc. Hort. Sci. 100:148-150.

Lau, O.L. and N.E. Looney. 1978. Effect of pre-storage high $\mathrm{CO}_{2}$ treatment on British Columbia and Washington Stare 'Golden Delicious' apples. J. Amer. Soc. Hort. Sci. 103:341-344.

Lidster, P.D.. F.R. Forsyth, and H.J. Lightfoot. 1980. Low oxygen and carbon dioxide atmosphere for storage of 'McIntosh' apples. Can. J. Plant Sci. 60:299-301.

Mattheis. J. and K. Olsen. 1989. Evaluation of commercial 'Delicious' apples stored at $1.1 \mathrm{C}$ and $3 \% \mathrm{CO}_{2}$, p. 287-294. In: J.K. Fellman (ed.). Proc. 5th Natl. Controlled Atmosphere Res. Conf., June 1989., Wenatchee, Wash.
Meheriuk, M. 1991. CA storage conditions for commercially grown apples. Compiled by: Meheriuk, Agr. Can. Res. Sta., Summerland, B.C., Canada.

Meheriuk, M., O.L. Lau, and J.W. Hall. 1984. Effect of some postharvest storage treatments in the incidences of flesh browning in controlled atmosphere stored 'Delicious' apples. J. Amer. Soc. Hort. Sci. 109:290293.

Meheriuk, M. and S.W. Pruitt. 1973. Effects of picking late, delayed storage, storage temperature and storage atmosphere in the quality of 'Starking' 'Delicious' apples. J. Amer. Soc. Hort. Sci. 53:593-595.

MSTAT. 1988. Version 1.0 Michigan State Univ., East Lansing, Mich.

Olsen, K.L. 1969. Controlled atmosphere storage of apples. Proc. Natl.

CA Res. Conf., Mich. State Univ. Hort. Rpt. 9:60-63.

Olsen, K.L. and R.D. Bartrum. 1978. Carbondioxide treatment of 'Golden Delicious' apples. USDA, SEA ATT-W2/September.

Olsen, K.L. and H.A. Schomer. 1964. Oxygen and carbon dioxiode levels for controlled atmosphere storage of 'Starking' and 'Golden Delicious' apples. USDA, AMS MRR653.

Patterson, M.E. and W.C. Nichols. 1988. Metabolic response of 'Delicious' apples to carbon dioxide in anoxic and low-oxygen environments. HortScience 23:866-868.

Patterson, M.E. and M. Workman. 1962. The influence of oxygen and carbon dioxide in the development of apple scald. Proc. Amer. Soc. Hort. Sci. 80:130-136.

Wang, C.Y. and W.M. Mellenthin. 1975. Effect of short term high CO, treatment on storage of d'Anjou pear. J. Amer. Soc. Hort. Sci. 100:492495.

Washington Agriculture Code 16-690-025. Washington controlled atmosphere storage requirements. 31 Mar. 1989.

Washington Apple Maturity Program Hdbk. 1986. Washington Apple Maturity Program, Wenatchee, Wash. 